University of Nebraska - Lincoln

DigitalCommons@University of Nebraska - Lincoln

\title{
Predicting Plant Extinction Based on Species-Area Curves in Prairie Fragments with High Beta Richness
}

\author{
Brian J. Wilsey \\ lowa State University \\ Leanne M. Martin \\ lowa State University \\ H. Wayne Polley \\ USDA-ARS Grassland, Soil and Water Research Laboratory, wayne.polley@ars.usda.gov
}

Follow this and additional works at: https://digitalcommons.unl.edu/usdaarsfacpub

Part of the Agricultural Science Commons

Wilsey, Brian J.; Martin, Leanne M.; and Polley, H. Wayne, "Predicting Plant Extinction Based on SpeciesArea Curves in Prairie Fragments with High Beta Richness" (2005). Publications from USDA-ARS / UNL Faculty. 424.

https://digitalcommons.unl.edu/usdaarsfacpub/424

This Article is brought to you for free and open access by the U.S. Department of Agriculture: Agricultural Research Service, Lincoln, Nebraska at DigitalCommons@University of Nebraska - Lincoln. It has been accepted for inclusion in Publications from USDA-ARS / UNL Faculty by an authorized administrator of DigitalCommons@University of Nebraska - Lincoln. 


\title{
Predicting Plant Extinction Based on Species-Area Curves in Prairie Fragments with High Beta Richness
}

\author{
BRIAN J. WILSEY,$\S$ LEANNE M. MARTIN, ${ }^{*} \ddagger$ AND H. WAYNE POLLEY $\dagger$ \\ ${ }^{*}$ Department of Ecology, Evolution and Organismal Biology, 353 Bessey Hall, Iowa State University, Ames, IA 50011, U.S.A. \\ †Grassland, Soil and Water Research Laboratory, USDA-ARS, Temple, TX 76502, U.S.A.
}

\begin{abstract}
Species-area relationships and island biogeography theory are commonly used to predict bow species richness will decline with fragmentation. There are a variety of largely untested assumptions in these approaches, including the assumptions that populations are distributed uniformly before fragmentation, and that local extinctions are due to effects of small population sizes. If populations are not distributed uniformly, then populations can be abundant locally but rare globally. This would cause extinction rates to be smaller than predicted. We tested extinction theory by developing estimates of the number of plant species that should be present in small tallgrass prairie fragments and then testing the uniformity assumption by partitioning species richness into $\alpha$ (within site) and $\beta$ (among site) components in Iowa prairies. Many more native prairie plant species were present in surveys of prairie fragments (491) than was predicted based on theory (27-207). A large proportion (75\%) of the total species richness was $\beta$ richness. We suggest that the high proportion of $\beta$ richness was responsible for the shallow species-area slopes and the lower than expected number of species losses and that a better understanding of what determines $\beta$ diversity will improve predictions of fragmentation effects on richness of plants. We also suggest that plants in prairie remnants may be best conserved by protecting different prairie types rather than by protecting a few large areas containing a single prairie type.
\end{abstract}

Key Words: beta diversity, biodiversity, extinction theory fragmentation, island biogeography theory, plant, species-area curves

Predicción de la Extinción de Plantas con Base en Curvas Especie-Área en Fragmentos de Pradera con Riqueza Beta Alta

Resumen: Las relaciones especies-área y la teoría de biogeografía de islas son usadas a menudo para predecir como declinará la riqueza de especies con la fragmentación. En estos métodos ay una variedad de suposiciones, en su mayoría no probadas, incluyendo las suposiciones de que las poblaciones están distribuidas uniformemente antes de la fragmentación, y que las extinciones locales se deben a los efectos de tamaños poblacionales pequeños. Si las poblaciones no se distribuyen uniformemente, entonces las poblaciones pueden ser abundantes localmente pero raras globalmente. Esto causaría que las tasas de extinción sean menores a lo pronosticado. Probamos la teoría de extinción mediante el desarrollo de estimaciones del número de especies de plantas que deberían estar presentes en pequeños fragmentos de pradera y posteriormente probamos la supuesta uniformidad mediante la partición de la riqueza de especies en componentes $\alpha$ (en el sitio) y $\beta$ (entre sitios) en praderas de Iowa. Encontramos mucho más especies de plantas de pradera en los muestreos de fragmentos de pradera (491) que lo pronosticado con base en la teoría (27-207). Una gran proporción (75\%) de la riqueza de especies total fue riqueza $\beta$. Sugerimos que la alta proporción de riqueza $\beta$ fue responsable de las pendientes especies-área reducidas y del número de pérdida de especies menor al esperado y que un mayor entendimiento de las causas que determinan la diversidad $\beta$ mejorará las predicciones de los efectos de la fragmentación sobre la riqueza de plantas. También sugerimos que las plantas en los remanentes

§email bwilsey@iastate.edu

¥Current address: Department of Biology, University of Nebraska-Omaba, Omaba, NE 68182, U.S.A.

Paper submitted July 22, 2004; revised manuscript accepted January 27, 2005. 
de pradera pueden ser mejor conservadas mediante la protección de diferentes tipos de pradera en lugar de proteger unas cuantas áreas extensas que solo contienen un tipo de pradera.

Palabras Clave: biodiversidad, curvas especie-área, diversidad beta, fragmentación, planta, teoría de extinción, teoría de biogeografía de islas

\section{Introduction}

A multitude of studies going back at least to Arrhenius (1921) reported strong positive relationships between species number and area (reviewed in Rosenzweig 1995). Species-area relationships have been studied at length to predict the number of species found on islands (MacArthur \& Wilson 1967; Kohn \& Walsh 1994; Rosenzweig 1995 ) and the effects of habitat fragmentation (Wilson 1992; Debinski \& Holt 2000; Cook et al. 2002) and to extrapolate species number to larger areas (Inouye 1998). Several theories have been developed to explain why species number changes with area, and most are based either on changes in local extinction and migration rates or on number of habitat types (reviewed by Rosenzweig 1995).

Species-area relationships (e.g., Rosenzweig 1995) and island biogeography theory (IBT, MacArthur \& Wilson 1967; Wilson 1992) continue to be commonly used to predict species loss with habitat fragmentation, especially in situations where little or no exchange occurs between patches (i.e., where metapopulation theory is less relevant [Hanski 1999]). According to IBT, a certain proportion of species is predicted to become extinct with each unit of habitat area that is lost. Populations of species are usually assumed to be large and uniformly distributed before fragmentation begins (e.g., Wilson 1992; Andrén 1994). As fragments become smaller, population sizes of rare species are predicted to be reduced, which increases the likelihood of local extinction. The increasing isolation of fragments leads to reduced migration between remaining fragments. Together, reduced migration and higher local extinction rates are predicted to lower species richness within fragments. Based on these assumptions, predictions are commonly made on the proportion of species that should be lost with a given amount of habitat loss based on the slope of the species-area relationship. For example, Wilson (1992) stated that 50\% of species richness will be lost with each $90 \%$ loss of area in tropical rainforest (log-log species-area slope $[z]$ of 0.30 ). A constant $z$ of 0.25 is used in many models based on the log-normal species abundance distribution (May 1975; Sugihara 1980; Thomas et al. 2004). More empirically oriented studies, however, emphasize that slopes are not constant (Conner \& McCoy 1979; Rosenzweig 1995; Gonzalez 2000) and that slopes vary with spatial scale (Williams 1964; Palmer \& White 1994; Crawley \& Harral 2001). Whether the slope is always as large and constant as is usually assumed in models is an important predic- tion that needs further testing with a variety of taxa in a variety of environments.

Other assumptions of extinction theory have not been fully tested for plant communities. For one, populations may not have been uniform originally. If most populations were originally globally rare but locally abundant (Simberloff $\&$ Abele 1976), then depending on how the fragmentation process proceeds, many populations would remain abundant if local patches were protected. If enough of these patches were protected, then global species richness would not decline as much as predicted. Thus, whether relationships between species richness and area are determined by area per se or by changes in the number of habitat types is a critical issue that has not been tested adequately (Conner \& McCoy 1979; Rosenzweig 1995).

We suggest that determining how much of regional diversity $(\gamma)$ is either $\alpha$ (within site) or $\beta$ (among site, Whittaker 1972) will be helpful in distinguishing between IBT and the habitat-types hypothesis. Island biogeography theory assumes species populations are reasonably uniform and implicitly predicts that most of $\gamma$ diversity should be $\alpha$ diversity (Andrén 1994). The habitat-types hypothesis predicts that much of $\gamma$ diversity should exist as $\beta$ diversity. Total (or $\gamma$ ) diversity can be partitioned into $\alpha$ and $\beta$ diversity with heterogeneity indices (e.g., Simpson's diversity index, Lande 1996) or by using species richness, which we do here. In either case, if the proportion of $\beta$ diversity is substantial, then predictions of IBT based on area per se will not accurately predict species loss because local populations will not be as small as predicted within each habitat type. This is illustrated in a simple example. With no $\beta$ richness and 100 species distributed uniformally, the mean relative abundance for a given species is $100 \% / 100$ species or $1 \%$ throughout. With higher $\beta$ richness (e.g., 100 species distributed across five habitat types containing 20 species each) the mean relative abundance is $100 \% / 20$ or $5 \%$ within each habitat. This gives an estimate of rarity that is five times lower. This should result in fewer extinctions than expected because local extinction rates increase with rarity (Fischer \& Stocklin 1997; Duncan \& Young 2000; Wilsey \& Polley 2004).

We developed predictions from species-area curves on how many species should be extant in prairie remnants in Iowa. Iowa is at the center of the tallgrass prairie biome and contains small remnant prairies scattered across the state. These remnants are widely separated and embedded 
within almost continuous agricultural lands (Dornbush 2004). Thus there is probably little or no migration between remnants because of the poor dispersal ability of prairie plant species (Rabinowitz \& Rapp 1980) and no spillover from the matrix (Brown \& Kodric-Brown 1977; Anderson \& Wait 2001; Cook et al. 2002), which makes the prairies an excellent system for testing the extinction theory. We addressed the following questions: (1) Is species richness in remaining Iowa prairie patches as low as that predicted based on theory? (2) If not, then is the proportion of $\gamma$ diversity that is $\beta$ diversity as low as it is commonly assumed? Results are highly relevant to the issue of how plants should be conserved, and whether conservation programs should be designed to protect many different prairie types or whether they should be designed to protect fewer larger prairies of one type (i.e., the single large preserve or several small preserves debate; Diamond 1976; Simberloff \& Abele 1976; Whitcomb et al. 1976).

\section{Methods}

We focused on plant species richness in the small tallgrass prairie remnants in Iowa (U.S.A.). The prairie system was large and continuous before European settlement and is now present only as very small fragments surrounded by agricultural lands. Remnants survived in part because of their importance as native hay fields or in a few cases as set-asides for future school or graveyard sites (Herzberg \& Pearson 2001). Thus remnants are not found solely on uncultivatable soils. Approximately $85 \%$ of Iowa was prairie originally, based on government surveys between 1832 and 1859 (Eilers \& Roosa 1994). It is estimated that only $0.1 \%$ of the original prairie remains as unplowed remnant "islands" (Samson \& Knopf 1994). Much of the surrounding land is used to grow corn and soybeans, with some pasturing of cattle in the southern and far western portions of the state.

We compared predictions based on theory with plant survey data from 22 (of 26) remnants that are in the Iowa state preserve system (the remaining 4 have not been sampled). Species lists were created for each prairie by various investigators as part of an Iowa Department of Natural Resources (DNR) Preserves program (Herzberg \& Pearson 2001). Some of these surveys have been published (e.g., Wetzel et al. 1999; Dornbush 2004), and some remain unpublished but are on record with the Iowa DNR. The objective of each survey was to find and identify all plant species present at each site during a given summer (Herzberg \& Pearson 2001). Two or three surveys were done in different years for some remnants (Table 1), with species richness showing no trend over time (paired $t=$ $1.14, p=0.30$ ). Because of this lack of a trend and to make data more comparable to sites with only one survey, we used the survey that was closest in date to others.
Table 1. Native species richness (no difference over time, paired $t$ test, $p=0.3$ ) in surveys of prairie remnants of Iowa.

\begin{tabular}{lcc}
\hline Prairie & Year & Species richness \\
\hline Clay & 1969 & 76 \\
& 2000 & 125 \\
Stiles & 1980 & 44 \\
& 1984 & 66 \\
Hayden & 1987 & 53 \\
& 1953 & 111 \\
Marietta & 1993 & 168 \\
& 1982 & 85 \\
Kalsow & 1998 & 88 \\
& 1953 & 126 \\
Doolittle & 2000 & 124 \\
& 1983 & 115 \\
& 1999 & 98 \\
\hline
\end{tabular}

We checked data for species synonyms and used a single taxonomy based on Eilers and Roosa (1994). Prairie remnants range in size from 1.2 to 95 ha and are managed with occasional (every few years) prescribed fires. Iowa remnants are scattered throughout the state in all the major ecoregions.

To develop predictions for species richness in remaining remnants, we used estimates of the number of species present in Iowa prairies before they were plowed (i.e., original $\gamma$ in species-area equations). Estimates of original species richness were from very early plant surveys of the entire state (Greene 1907) and from statewide herbarium collections from 1870 to 1933 (Cratty 1933). These values were used in the general equation for species-area relationships to predict how many species should remain. We used the general equation for species-area relationships: $S=c A^{z}$, where $S$ is the number of species, $c$ is a constant, $A$ is area, and $z$ is the slope of $\log$-log plots (Rosenzweig 1995). In calculating richness, we excluded non-native, woody (with the exceptions of the common prairie forbs Amorpha and Ceanothus), and forest herb species from our analyses. Thus we included only native prairie species. Wet prairie species were included, but floating, submerged, and streambank aquatic plant species were not.

Current $\gamma$ richness was estimated by combining the total number of species identified during all 22 surveys of Iowa prairies (Herzberg \& Pearson 2001). This most likely is an underestimate of total $\gamma$ richness because sites were not surveyed over many years and in all seasons. We then partitioned $\gamma$ richness into $\alpha$ (within prairie) and $\beta$ (among prairies) components (Lande 1996; Crist et al. 2003). Alpha richness was estimated by counting the number of species identified within each prairie. Beta richness was estimated using the additive partitioning model of Lande (1996): $\gamma=\alpha+\beta$, where $\alpha$ is mean richness and $\beta$ is $\gamma-\alpha$. This puts $\alpha$ and $\beta$ richness in the same units and allows a direct comparison of the proportion of each (Lande 1996; Loreau 2000; Veech et al. 2002; 
Table 2. Predictions from species-area extinction theory of the number of plant species $(S)$ that should be extant in all Iowa prairie remnants, which make up $0.1 \%\left(124 \mathrm{~km}^{2}\right.$, Samson \& Knopf 1994) of their original $\left(123,893 \mathrm{~km}^{2}\right)$ extent, or in the area encompassing the 22 preserves that have been sampled $\left(7.12 \mathrm{~km}^{2}\right)$.

\begin{tabular}{|c|c|c|c|c|c|c|}
\hline & \multicolumn{3}{|c|}{ Original $^{*}$} & \multicolumn{3}{|c|}{ Current } \\
\hline Green (1907) & 0.15 & 5.81 & 138.73 & 2.06 & 285.8 & 186.2 \\
\hline & 0.20 & 10.44 & 77.20 & 2.62 & 202.3 & 114.3 \\
\hline & 0.25 & 18.76 & 42.96 & 3.34 & 143.5 & 70.0 \\
\hline & 0.30 & 33.72 & 23.90 & 4.25 & 101.6 & 43.1 \\
\hline & 0.35 & 60.61 & 13.30 & 5.40 & 71.8 & 26.5 \\
\hline & 0.20 & 10.44 & 85.92 & 2.62 & 225.1 & 127.2 \\
\hline & 0.25 & 18.76 & 47.81 & 3.34 & 159.7 & 78.1 \\
\hline & 0.30 & 33.72 & 26.60 & 4.25 & 113.1 & 47.9 \\
\hline & 0.35 & 60.61 & 14.80 & 5.40 & 79.9 & 29.4 \\
\hline
\end{tabular}

${ }^{*}$ Estimates of the original number of native prairie species were 806 species (Greene 1907) or 897 species (Cratty 1933). The actual number of species found in surveys of 22 of the 26 remaining remnants was 491.

Crist et al. 2003). Again, we excluded non-native, woody, forest herb, and streambank species from our analysis.

We regressed the number of species per remnant $(\alpha)$ against remnant $\ln$ (area) to determine whether current richness is related to remnant size within Iowa. An alternative hypothesis is that $\alpha$ richness is a function of geological region. Iowa contains several geological regions that vary in glacial history (Des Moines Lobe was glaciated during the last ice age, whereas other regions were not), soil type (high silt content in loess hills prairies, high sand content in sand prairies, and high clay content in other prairies), and precipitation (high of $864 \mathrm{~mm}$ in the southeast, low of $660 \mathrm{~mm}$ in the northwest; Eilers \& Roosa 1994). Variation among regions is important because it gives rise to $\beta$ richness. Thus, analyses were done on $\alpha$ richness as a function of both remnant area and geological region in a general linear model.

\section{Results}

\section{Predicted Species Richness}

Based on the assumption that $85 \%$ of Iowa consisted of prairie (Eilers \& Roosa 1994), we calculated that 123,893 $\mathrm{km}^{2}$ of the state were originally prairie (original area $[A]$ ). An estimated $0.1 \%$ of the state (or $124 \mathrm{~km}^{2}$ ) is now unplowed prairie (Samson \& Knopf 1994). Using the usually assumed value for $z$ of 0.25 based on the log-normal rank-abundance distribution (May 1975; Sugihara 1980), and an estimated 806 (Greene 1907) or 897 (Cratty 1933) original prairie species from early botanical surveys, we calculated $c$ values $\left(c=S / A^{z}\right)$ of 43.0 and 47.8. We used these values of $c$ to predict how many species should occur in $0.1 \%$ of the original prairie:

$$
\begin{aligned}
& S=43.0 \times 124^{0.25}, S=143, \text { or } \\
& S=47.8 \times 124^{0.25}, S=160 .
\end{aligned}
$$

For the actual area of the remnants sampled during the 22 surveys $\left(7.12 \mathrm{~km}^{2}\right)$,

$$
\begin{aligned}
& S=43 \times 7.12^{0.25}, S=70, \text { or } \\
& S=47.8 \times 7.12^{0.25}, S=78 .
\end{aligned}
$$

Predictions of $S$ within the surveyed area ranged from $27(z=0.35$ and original species estimate of 806 ; Greene 1907) to 207 ( $z=0.15$ and original species estimate of 897; Cratty 1933) (Table 2). The value of $c$ influences the number of species in a way that is largely opposite the effect of the value of $z$.

\section{Actual Species Richness}

A total of 491 native species ( $\gamma$ richness) were found during the surveys of 22 prairie remnants. This represents $85 \%$ of the total number of plant species encountered (including native and exotic species, 95\% CI: 82-87). In other words, $15 \%$ of all species encountered in the remnants were exotic species. Excluding exotic species and using the estimated 491 native species, remnants contained an estimated 2-18 times more species than predicted (27-207) based on IBT. Based on 491 species encountered, and a $z$ value of 0.25 , presettlement Iowa would have had to have 2760 prairie species for predictions to be correct.

Alpha species richness among surveyed remnants was affected more by geological region than by the size of the remnant (Fig. 1). A mean of 122.3 species occurred per prairie. Alpha richness was not related to remnant area (range 1.2-95.9 ha) when geological region was not accounted for $\left(F_{1,20}=1.2, p=0.26\right)$ and was weakly related to area when geological region was included in the model $\left(F_{1,15}=5.1, p=0.04\right)$. There was no interaction between area and geological region $(p=0.37)$. Log-transformed area accounted for only $14.1 \%$ of the variance in amongprairie $\alpha$ richness with a slope of 0.07 (Fig. 1). Remnants 


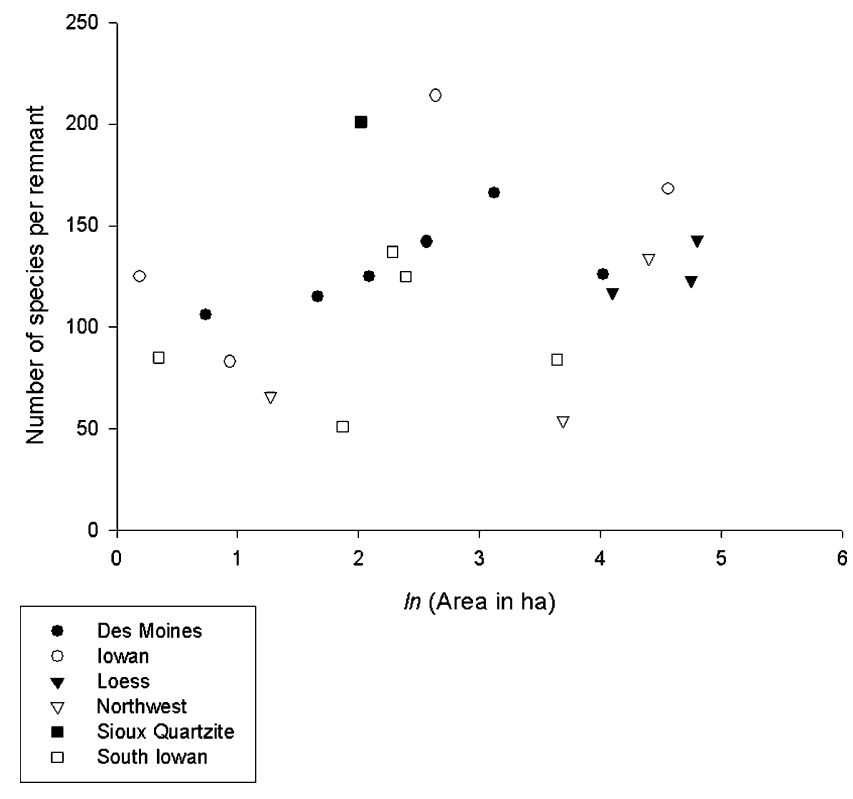

Figure 1. Relationship between current species richness per remnant and natural log area (ba) in surveyed remnants among geological regions. The Des Moines Lobe is the only area that was glaciated during the last ice age.

varied by about two orders of magnitude in area, ranging from 1.2 to 95.9 ha. Even very small remnants contained a large number of species. For example, the three smallest prairies, Pohl Prairie (2.1 ha), Clay Prairie (1.2 ha), and Marietta Sand Prairie (1.4 ha), contained 106, 125 , and 85 species, respectively, which are all greater than the IBT estimates for all prairie remnants combined. Species richness per prairie varied significantly across geological regions $\left(F_{5,15}=3.8, p=0.02\right)$. Geological region accounted for much more of the variance than did remnant area: $53 \%$ of the variance $\left(r^{2}\right)$ in among-prairie $(\alpha)$ species richness was attributed to region. Alpha richness was highest in the only prairie on Sioux Quartzite and in the Iowan Surface land-form region and was lowest in prairies in the Northwestern Iowa Plains Region (Figure 1).

Most of total $(\gamma)$ species richness consisted of $\beta$ richness. There was a mean of $75.2 \% \beta$ richness and $24.8 \%$ $\alpha$ richness. The $95 \%$ confidence interval for the $75.2 \% \beta$ was $71-79 \%(n=22)$.

\section{Discussion}

Species-area theory and IBT (with assumptions of constant slope of 0.25 and uniform distribution of species) predict that the number of plant species remaining in Iowa prairies during the late twentieth century after
99.9\% of the prairie system had been converted to other land uses was very low (143 or 160 species). A less restrictive approach that brackets estimates with $z$ values ranging from 0.15 to 0.35 (Wilson 1992) yielded estimates ranging from 72 to 318 species. Data from comprehensive surveys of Iowa prairies showed that IBT vastly underestimated the number of species that remain (491 species in surveys of 22 protected remnants with a combined area of $7.12 \mathrm{~km}^{2}$ ).

Extinction theory underestimated the richness remaining in prairie remnants for at least two reasons: species could be "the living dead," doomed to a slow extinction (Wilson 1992; Tilman et al. 1994), or the higher-thanexpected proportion of $\beta$ diversity ( $75 \%$ of total) complicated predictions because many different prairie types were protected under the Iowa state preserve system. We have no way of disproving the first hypothesis, although the very long period between the time that Iowa was first plowed during the mid- to late 1800s and now (2004) means the extinction rate would be much slower than previously thought. The second hypothesis seems more likely, and our finding that much of species richness was $\beta$ richness supports this.

Variations in topography and soil type led to high species turnover across space. Prairies range from blacksoil prairies containing high concentrations of clay to loess prairies containing silty soil to sand prairies formed on riverine sediments. Crawley and Harral (2001) found that $z$ can change with spatial scale, with the highest $z$ values associated with intermediate scales (0.4-0.5 vs. $0.1-0.2$ at both smaller and larger scales). The intermediate scale is where geology and topography create species turnover, or high $\beta$ richness (Crawley \& Harral 2001). The protection of prairies within each of the major ecoregions of the state could have prevented the expected rapid decline in richness during the intermediate stage of fragmentation when whole community types were being lost. Other recent studies show a larger-than-expected proportion of $\beta$ richness in plant communities (Wagner et al. 2000; Condit et al. 2002; Harrison \& Inouye 2002), and Nichols et al. (1998) found important geomorphological variation among Rhode Island forests. A better mechanistic understanding of what controls $\beta$ diversity (Loreau 2000; Veech et al. 2002) and additional estimates of how much diversity exists as $\beta$ across a variety of environments will be helpful in developing more accurate predictions for systems that are just beginning to experience fragmentation.

Evidence exists that very small midwestern U.S.A. prairie remnants are losing native species (Leach \& Givnish 1996), but we did not measure local extinction rate per se. There were fewer native prairie species in the remnant surveys (491) than in the early state-wide surveys of Greene (1907) (806 species) or in herbarium specimens collected between 1870 and 1933 by Cratty (1933) (897 species). Although the current surveys did not include 
all extant species and therefore underestimated actual species richness, the large difference between the recent and old surveys suggests that substantial amounts of extinction have occurred with fragmentation of the originally extensive tallgrass prairie. Our analyses indicate, however, that that theory overestimates the number of species that should have been lost.

Wilson (1992) speculated that extinction rates should be even larger than expected from species area curves when remnant area drops below $1 \%$, as it did here $(0.1 \%$ remaining). This prediction, however, did not hold true. Even tiny remnants continued to support a large number of native species. Relationships between remnant area and species richness were weak, and most of the variation in species richness was explained by geological region, which is a broad descriptor of glacial history and soil type. Results of studies suggest that extinction theory may do a better job of predicting species loss under fragmentation in animals than in plants. This is especially true for arthropods (Debinski \& Holt 2000) and animals with large home ranges (Diamond 1976; Andrén 1994). We looked only at plants, which are traditionally thought to be more affected by small-scale variation in soil type and microtopography. Our results verify this thought.

Experimental evidence for higher extinction rates in small Amazon forest fragments provides support for the idea that small fragments will lose more species (Lovejoy et al. 1986), but the question is how many species will be lost with fragmentation. We suggest that predictions from IBT may be more accurate for areas of low terrain heterogeneity such as the Amazon, where the proportion of diversity that is $\beta$ is lower than it is for regions with higher terrain heterogeneity (Condit et al. 2002). Nevertheless, our results suggest that it may not be wise to make predictions about fragmentation without considering the amount of $\beta$ diversity that is likely to exist in an area, which will be a function of the amount of geomorphological heterogeneity (Nichols et al. 1998; Condit et al. 2002; this study) or the presence or absence of animal activities (Knapp et al. 1999; Klaas et al. 2000). We suggest that a better understanding of $\beta$ diversity will be helpful in developing new and improved biogeographical models to explain discrepancies (Lomolino 2000).

Our results indicate that plants in prairie communities may be best conserved by protecting different prairie types rather than by protecting a few large sites containing a single prairie type. Gering et al. (2003) made the same suggestion for conserving insect diversity in deciduous forests. Prairies vary greatly depending on soil type and geological region, even within the tallgrass prairie biome. A single large remnant from only one of these types will not protect species in other types. Our results also support the contention by Cully et al. (2003) that small remnants are important from a conservation standpoint and deserve to be protected whenever possible.

\section{Acknowledgments}

We thank J. Pearson and T. Rosburg for help with organizing the Iowa data set. This study would not have been possible without the data sets collected by T. Cady, P. Christiansen, G. H. Crum, M. Dornbush, A. Duxbury, R. W. Freckman, E. L. Freese, D. C. Glen-Lewin, C. W. Lantz, J. F. Moyer, W. Schwennum, D. M. Vander Zee, M. D. Wagner, P. R. Wetzel, W. R. Norris, K. M. Lyles, T. Wilson, and G. Woodley.

\section{Literature Cited}

Anderson, W. B., and D. A. Wait. 2001. Subsidized island biogeography hypothesis: another new twist on an old theory. Ecology Letters 4:289-291.

Andrén, H. 1994. Effects of habitat fragmentation on birds and mammals in landscapes with different proportions of suitable habitat: a review. Oikos 71:355-366.

Arrhenius, O. 1921. Species and area. Journal of Ecology 9:95-99.

Brown, J. H., and A. Kodric-Brown. 1977. Turnover rates in insular biogeography: the effect of immigration on extinction. Ecology 58: 445-449.

Cook, W. M., K. T. Lane, B. L. Foster, and R. D. Holt. 2002. Island theory, matrix effects and species richness patterns in habitat fragments. Ecology Letters 5:619-623.

Condit, R., et al. 2002. Beta-diversity in tropical forest trees. Science 295:666-669.

Conner, E. F., and E. D. McCoy. 1979. The statistics and biology of the species-area relationship. The American Naturalist 113:791-833.

Cratty, R. I. 1933. The Iowa flora: an annotated list of the ferns, fern allies and the native and introduced flowering plants of the state represented in the Iowa State College herbarium. Iowa State College Journal of Science 7:177-252.

Crawley, M. J., and J. E. Harral. 2001. Scale dependence in plant biodiversity. Science 291:864-868.

Crist, T. O., J. A. Veech, J. C. Gering, and K. S. Summerville. 2003. Partitioning species diversity across landscapes and regions: a hierarchical analysis of $\alpha, \beta$, and $\gamma$ diversity. The American Naturalist 162:734-743.

Cully, A. C., J. F. Cully Jr., and R. D. Hiebert. 2003. Invasion of exotic plant species in tallgrass prairie remnants. Conservation Biology 17: 990-998.

Debinski, D. M., and R. D. Holt. 2000. A survey and overview of habitat fragmentation experiments. Conservation Biology 14:342-355.

Diamond, J. 1976. Island biogeography and conservation: strategy and limitations. Science 193:1027-1029.

Dornbush, M. E. 2004. Plant community change following fifty years of management at Kalsow Prairie Preserve, Iowa, U.S.A. American Midland Naturalist 151:241-250.

Duncan, R. P., and J. R. Young. 2000. Determinants of plant extinction and rarity 145 years after European settlement of Auckland, New Zealand. Ecology 81:3048-3062.

Eilers, L. J., and D. M. Roosa. 1994. The vascular plants of Iowa. University of Iowa Press, Iowa City.

Fischer, M., and J. Stocklin. 1997. Local extinctions of plants in remnants or extensively used calcareous grasslands, 1950-1985. Conservation Biology 11:727-737.

Gering, J. C., T. O. Crist, and J. A. Veech. 2003. Additive partitioning of species diversity across multiple spatial scales: implications for regional conservation of biodiversity. Conservation Biology 17: 488-499. 
Gonzalez, A. 2000. Community relaxation in fragmented landscapes: the relation between species richness, area and age. Ecology Letters 3:441-448.

Greene, W. 1907. Plants of Iowa: a preliminary list of the native and introduced plants of the state not under cultivation. Bulletin of the State Horticulture Society 1-264

Hanski, I. 1999. Metapopulation ecology. Oxford Univsity Press, Oxford, United Kingdom.

Harrison, S., and B. D. Inouye. 2002. High $\beta$ diversity in the flora of California serpentine "islands." Biodiversity and Conservation 11:18691876.

Herzberg, R., and J. Pearson. 2001. The guide to Iowa's state preserves. University of Iowa Press, Iowa City.

Inouye, R. S. 1998. Species-area curves and estimates of total species richness in an old-field chronosequence. Plant Ecology 137: 31-40

Klaas, B. A., K. A. Moloney, and B. J. Danielson. 2000. The tempo and mode of gopher mound production in a tallgrass prairie remnant. Ecography 23:246-256.

Kohn, D. D., and D. M. Walsh. 1994. Plant species richness-the effect of island size and habitat diversity. Journal of Ecology 82:367377.

Knapp, A. K., J. M. Blair, J. M. Briggs, S. L. Collins, D. C. Hartnett, L. C. Johnson, and E. G. Towne. 1999. The keystone role of bison in North American tallgrass prairie. BioScience 49:39-50.

Lande, R. 1996. Statistics and partitioning of species diversity, and similarity among multiple communities. Oikos 76:5-13.

Leach, M. K., and T. J. Givnish. 1996. Ecological determinants of species loss in remnant prairies. Science 273:1555-1558.

Lomolino, M. V. 2000. A call for a new paradigm of island biogeography. Global Ecology and Biogeography 9:1-6.

Loreau, M. 2000. Are communities saturated? On the relationship between $\alpha, \beta$ and $\gamma$ diversity. Ecology Letters 3:73-76.

Lovejoy, T. E., et al. 1986. Edge and other effects of isolation on Amazon forest fragments. Page 257-286 in M. E. Soulé, editor. Conservation biology: the science of scarcity and diversity. Sinauer, Sunderland, Massachusetts.

MacArthur, R. H., and E. O. Wilson. 1967. The theory of island biogeography. Princeton University Press, Princeton, New Jersey.

May, R. M. 1975. Patterns of species abundance and diversity. Pages 81-120 in M. L. Cody and J. M. Diamond editors. Ecology and evo- lution of communities. Harvard University Press, Cambridge, Massachusetts.

Nichols, W. F, K. T. Killingbeck, and P. V. August. 1998. The influence of geomorphological heterogeneity on biodiversity. II. A landscape perspective. Conservation Biology 12:371-379.

Palmer, M. W., and P. S. White. 1994. Scale dependence and the speciesarea relationship. The American Naturalist 144:717-724.

Rabinowitz, D., and J. K. Rapp. 1980. Seed rain in a North American tallgrass prairie. Journal of Applied Ecology 17:793-802.

Rosenzweig, M. L. 1995. Species diversity in space and time. Cambridge University Press, Cambridge, United Kingdom.

Samson, R., and F. Knopf. 1994. Prairie conservation in North America. BioScience 44:418-421.

Simberloff, D. S., and L. C. Abele. 1976. Island biogeography theory and conservation practice. Science 191:285-286.

Sugihara, G. 1980. Minimal community structure: an explanation of species abundance patterns. The American Naturalist 116:770

Thomas, C. D., et al. 2004. Extinction risk from climate change. Nature 427:145-148.

Tilman, D., R. M. May, C. L. Lehman, and M. A. Nowak. 1994. Habitat destruction and the extinction debt. Nature 371:65-66.

Veech, J. A., K. S. Summerville, T. O. Crist, and J. C. Gering. 2002. The additive partitioning of species diversity: recent revival of an old idea. Oikos 99:3-9

Wagner, H. H., O. Wildi, and K. C. Ewald. 2000. Additive partitioning of plant species diversity in an agricultural mosaic landscape. Landscape Ecology 15:219-227.

Wetzel, P. R., W. R. Norris, and K. M. Lyles. 1999. The vascular flora of Doolittle Prairie State Preserve-a prairie pothole wetland complex. Journal of the Iowa Academy of Science 106:26-33.

Whitcomb, R. F., J. F. Lynch, P. A. Opler, and C. S. Robbins. 1976. Island biogeography and conservation: strategy and limitations. Science 193:1030-1032.

Whittaker, R. H. 1972. Evolution and measurement of species diversity. Taxon 21:213-251

Williams, C. B. 1964. Patterns in the balance of nature. Academic Press, London, United Kingdom.

Wilsey, B. J., and H. W. Polley. 2004. Realistically low species evenness does not alter grassland species richness-productivity relationships. Ecology 85:2693-2701

Wilson, E. O. 1992. The diversity of life.W. W. Norton, New York.

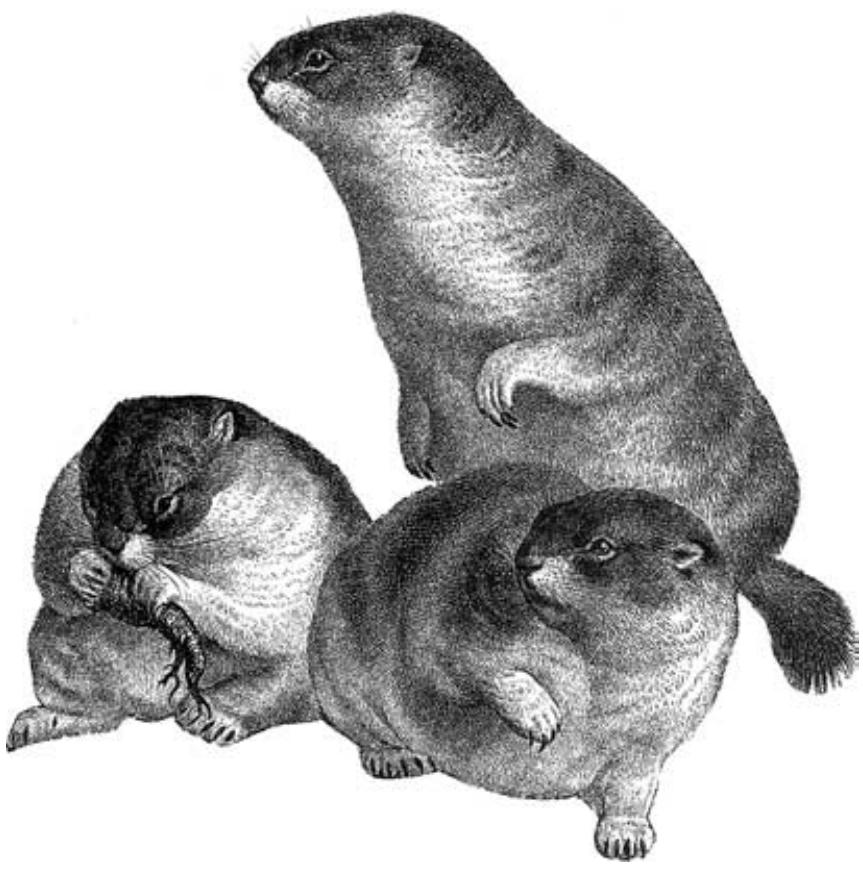

